\title{
GATA4 knockdown in MA-10 Leydig cells identifies multiple target genes in the steroidogenic pathway
}

\author{
Francis Bergeron ${ }^{1}$, Gabriel Nadeau ${ }^{1}$ and Robert S Viger ${ }^{1,2}$ \\ ${ }^{1}$ Reproduction, Mother and Child Health, Room T3-67, Centre de Recherche du Centre Hospitalier Universitaire \\ (CHU) de Québec, Centre de Recherche en Biologie de la Reproduction (CRBR), 2705 Laurier Boulevard, \\ Quebec City, Quebec, Canada G1V 4G2 and ${ }^{2}$ Department of Obstetrics and Gynecology, Faculty of Medicine, \\ Laval University, Quebec City, Quebec, Canada G1K 7P4
}

Correspondence should be addressed to R S Viger; Email: robert.viger@crchul.ulaval.ca

\begin{abstract}
GATA4 is an essential transcription factor required for the initiation of genital ridge formation, for normal testicular and ovarian differentiation at the time of sex determination, and for male and female fertility in adulthood. In spite of its crucial roles, the genes and/or gene networks that are ultimately regulated by GATA4 in gonadal tissues remain to be fully understood. This is particularly true for the steroidogenic lineages such as Leydig cells of the testis where many in vitro (promoter) studies have provided good circumstantial evidence that GATA4 is a key regulator of Leydig cell gene expression and steroidogenesis, but formal proof is still lacking. We therefore performed a microarray screening analysis of MA-10 Leydig cells in which Gata4 expression was knocked down using an siRNA strategy. Analysis identified several GATA4-regulated pathways including cholesterol synthesis, cholesterol transport, and especially steroidogenesis. A decrease in GATA4 protein was associated with decreased expression of steroidogenic genes previously suspected to be GATA4 targets such as Cyp11a1 and Star. Gata4 knockdown also led to an important decrease in other novel steroidogenic targets including Srd5a1, Gsta3, Hsd3b1, and Hsd3b6, as well as genes known to participate in cholesterol metabolism such as Scarb1, Ldlr, Soat1, Scap, and Cyp51. Consistent with the decreased expression of these genes, a reduction in GATA4 protein compromised the ability of MA-10 cells to produce steroids both basally and under hormone stimulation. These data therefore provide strong evidence that GATA4 is an essential transcription factor that sits atop of the Leydig cell steroidogenic program.

Reproduction (2015) 149 245-257
\end{abstract}

\section{Introduction}

GATA-binding protein 4 (GATA4) is a transcription factor belonging to the GATA family of zinc finger proteins. It is critically required for the development and function of multiple tissues derived from both mesoderm and endoderm (reviewed in Molkentin (2000), Viger et al. (2008) and Chlon \& Crispino (2012)). This includes both the testis and ovary where GATA4 is one the earliest markers of gonadal development. It is expressed in the coelomic epithelial layer of the genital ridge, starting at around E.10.0 in the mouse (Mazaud Guittot et al. 2007, $\mathrm{Hu}$ et al. 2013). Following gonadal differentiation, GATA4 remains highly expressed in all gonadal somatic lineages of both sexes throughout ontogeny (reviewed in LaVoie (2003), Viger et al. (2004, 2008) and Zaytouni et al. (2011)). In the ovary, this includes granulosa, theca, and luteal cells. In the testis, GATA4 is found in peritubular, Leydig, and Sertoli cells. The presence of GATA4 protein in Sertoli cells (Imai et al. 2004) and the activity of Gata 4 promoter regulatory sequences driving Sertoli cell expression (Mazaud Guittot et al. 2007) are independent of the stage of germ cell maturation making this gene and its promoter a highly useful and frequently used marker for this cell type.

Several conditional and gonad-specific knockout mouse models have provided important insights into the in vivo roles played by GATA4 in gonadogenesis. Consistent with its very early expression at the stage of coelomic epithelial thickening, conditionally Gata4deficient $X X$ or $X Y$ embryos do not initiate the formation of a genital ridge (Hu et al. 2013). Elegant mouse models used by Tevosian et al., where the Gata4 gene was excised around the time of sex determination by gonadspecific Cre drivers, have shown that GATA4 is also essential for normal testicular and ovarian differentiation (reviewed in Tevosian (2014)). These crucial functions in early mammalian gonadogenesis necessitate not only GATA4 but also a functional cooperation between GATA4 and its transcriptional partner Friend of GATA 2 (FOG2/ZFPM2; Tevosian et al. 2002, Manuylov et al. 2008, 2011). The requirement for GATA4 protein in testis and ovary is maintained during later fetal development and into adulthood, as several different groups have 
reported that loss of GATA4 at these stages is associated with disrupted cord formation and impaired spermatogenesis in the testis (Kyrönlahti et al. 2011a, Manuylov et al. 2011), and impaired granulosa cell proliferation, theca cell recruitment, and a failure of follicular development ultimately leading to reduced fertility in the adult female (Kyrönlahti et al. 2011b, Bennett et al. 2012, Efimenko et al. 2013).

Important insights into the mechanism of action of GATA4 in gonadal development and function have also come from the identification of some of its target genes. Some of the earliest genes acting downstream of GATA4 in the genital ridge and differentiating testis include steroidogenic factor $1 /$ adrenal 4-binding protein (Nr5a 1), LIM homeobox protein 9 (Lhx9), sex determining region of chromosome $\mathrm{Y}$ (Sry), SRY-box containing gene 9 (Sox9), and anti-Müllerian hormone Amh (Tevosian et al. 2002, Manuylov et al. 2007, Hu et al. 2013). In vitro and in vivo studies have suggested that some of these genes are direct targets for GATA4, acting in their $5^{\prime}$ regulatory (promoter) regions (Viger et al. 1998, Tremblay \& Viger 2001, Tevosian et al. 2002, Manuylov et al. 2007, Miyamoto et al. 2008, Hu et al. 2013). In the newly formed testis, conditional loss of Gata4 expression highlighted the requirement for GATA4 in sustaining testis cord morphogenesis by promoting the expression of the Dmrt1 gene (Manuylov et al. 2011), whose promoter also appears to be under direct GATA4 control (Lei \& Heckert 2004).

Another class of potential GATA4-regulated gene targets in gonadal cells is genes involved in the steroidogenic pathway (reviewed in LaVoie (2003), Tremblay \& Viger (2003a) and Viger et al. (2008)). Proposed steroidogenic targets for GATA4 identified through in vitro promoter characterization studies have included steroidogenic acute regulatory protein (Star), P450 cholesterol side chain cleavage (Cyp11a1), steroid $17 \alpha$-hydroxylase (Cyp17a1), 33-HSD type 2 (HSD3B2), and P450 aromatase (Cyp19a1) (reviewed in Viger et al. (2008), Shi et al. (2009) and King \& LaVoie (2012)). Proof that these genes are indeed direct targets for GATA transcriptional regulation, however, has yet to be formally provided. While conditional knockout of Gata4, or of Gata4 and Gata6 in the ovary, is associated with decreased expression of some of the genes (Cyp19a1, Cyp11a1, and Star; Kyrönlahti et al. 2011b, Bennett et al. 2012), it remains unclear whether they are actual GATA4 transcriptional targets given the important disruption in folliculogenesis that is associated with the knockouts. In comparison to Sertoli cells of the testis, conditional Gata4 knockout models have been less useful for studying steroidogenic (Leydig) cells, as reliable Leydig cell-specific Cre drivers, especially in the adult, are lacking. Moreover, GATA4 protein appears to be essential for the development and differentiation of steroidogenic cells in the fetal testis, which further compounds the problem (Tevosian et al. 2002,
Bielinska et al. 2007). To circumvent these difficulties and to identify novel GATA4-regulated gene targets in Leydig cells, we performed a microarray screening analysis of MA-10 Leydig cells, in which Gata4 expression was knocked down using siRNAs directed against the Gata4 coding sequence. Our results show that GATA4 is essential for steroid production in MA-10 cells by regulating the expression of several key genes required for steroidogenesis.

\section{Materials and methods \\ GATA4 siRNA-mediated knockdown in MA-10 cells}

MA-10 Leydig cells were plated in $60 \mathrm{mM}$ petri dishes and transfected the next day at 50-60\% confluence with $150 \mathrm{nM}$ of predesigned Stealth RNAi molecules purchased from Invitrogen directed against the GATA4 coding sequence and Stealth RNAi Negative Control Duplexes (Invitrogen, cat. no. 12935300) used as negative controls. Two different siRNA sequences against GATA4 were used in this study, both giving comparable results - GATA4MSS247223: 5' - CCAAUCUCGAUAUGUUUGAUGACUU-3'; GATA4MSS247225: 5'- UCCAUCCAGUGCUGUCUGCUCUGAA-3'. The siRNA was transfected using $16 \mu \mathrm{l}$ of jetPRIME transfection reagent and $200 \mu \mathrm{l}$ of jetPRIME transfection buffer (Polyplus transfection, New York, NY, USA). The cell media was changed the day after transfection; $48 \mathrm{~h}$ later, half of the cells were collected for RNA extraction and the other half for total protein extraction. For the Star promoter luciferase assay, $500 \mathrm{ng} /$ well of a WT or GATA mutated Star promoter construct was cotransfected with $150 \mathrm{nM}$ of siRNA GATA4MSS247225 using $2.5 \mu \mathrm{l} /$ well of jetPRIME in MA-10 cells at $50-60 \%$ confluence. The media was changed $24 \mathrm{~h}$ after transfection and cells were assayed for luciferase activity as described previously.

\section{RNA isolation}

Total RNA was extracted by TRI reagent (Invitrogen) according to the manufacturer's instructions. RNA quantity and purity were determined by absorbance at 260/280 nm and RNA integrity by agarose gel electrophoresis. For the microarray experiment, total RNA was further purified using an RNeasy $>t$ column (Qiagen), and the integrity of the RNA was assessed using an Agilent Bioanalyzer (Agilent Technologies Canada, Inc., Mississauga, Ontario, Canada).

\section{$R T$ and quantitative real-time PCR}

First-strand cDNAs were synthesized from a $1 \mu \mathrm{g}$ aliquot of total RNA using random hexamer nucleotides and Superscript III reverse transcriptase (Invitrogen) according to the manufacturer's protocol. Real-time qPCR was performed with $2 \mu \mathrm{l}$ of cDNA using a LightCycler 1.5 instrument and the LightCycler FastStart DNA Master SYBR Green I Kit (Roche Diagnostics Canada). The primers used for qPCR are given in Table 1 . The following conditions were used for qPCR: $10 \mathrm{~min}$ at $95^{\circ} \mathrm{C}$ followed by 40 cycles of denaturation $\left(5 \mathrm{~s}\right.$ at $\left.95^{\circ} \mathrm{C}\right)$, annealing $\left(60-62{ }^{\circ} \mathrm{C}\right)$, and extension $\left(20 \mathrm{~s}\right.$ at $\left.72^{\circ} \mathrm{C}\right)$ with a single 
Table 1 Oligonucleotide primers used for qPCR analysis.

\begin{tabular}{|c|c|}
\hline Gene product & Sequence \\
\hline \multirow[t]{2}{*}{ Gata4 } & F: 5'-CTCTGGAGGCGAGATGGGAC-3' \\
\hline & R: 5'-CGCATTGCAAGAGGCCTGGG-3' \\
\hline \multirow[t]{2}{*}{ Amhr2 } & F: 5'-СССТCTGCССТCTGGGCCTT-3' \\
\hline & R: 5'-ACTGGCCATCCTGCCAACGC-3' \\
\hline \multirow{2}{*}{ Cyp11a1 } & F: 5'-CACCAGTATTATCAGAGGCCC-3' \\
\hline & R: 5'-GATGAAGTCCTGAGCTACACC-3' \\
\hline \multirow[t]{2}{*}{ Gsta3 } & F: 5'-TGGCGGGGAAGCCAGTCCTT-3' \\
\hline & R: 5'-ACCTTGCCAGGTCATCCCGAGT-3' \\
\hline \multirow[t]{2}{*}{ Hsd3b1 } & F: 5'-GGCTGGATGGAGCTGCCTGG-3' \\
\hline & R: 5'-GCTCTCCTCAGGCACTGGGC-3' \\
\hline \multirow[t]{2}{*}{ Hsd3b6 } & F: 5'-TGTCACAGGTGTCATTCCCAGGCA-3' \\
\hline & R: 5'-CTCTTCCTCGTTGCCATTCAGGATT-3' \\
\hline \multirow[t]{2}{*}{ Inha } & F: 5'-CGAACTTGTCCGGGAGCTCGT-3' \\
\hline & R: 5'-TGGCTGGTCCTCACAGGTGGC-3' \\
\hline \multirow[t]{2}{*}{ Srd5a1 } & F: $5^{\prime}$-TCTGATCCACTACGTGCAAAG-3' \\
\hline & R: 5'-TCAAGTATCGGCTCTGCAAG-3' \\
\hline \multirow[t]{2}{*}{ Star } & F: 5'-CAACTGGAAGCAACACTCTA-3' \\
\hline & R: 5'-CCTTGACATTTGGGTTCCAC-3' \\
\hline \multirow[t]{2}{*}{$\operatorname{ltg} b 8$} & F: 5'-GCTTTGCATTATGTGCGGCT-3' \\
\hline & R: 5'-TGGCACAGGAGACCACATTT-3' \\
\hline \multirow[t]{2}{*}{ Vcan } & F: 5'-CGGACCTATGGATTCCGCTC-3' \\
\hline & R: 5'-AGTTCTCCAACAGTCGCCAG-3' \\
\hline \multirow[t]{2}{*}{ Sumo3 } & F: 5'-GGGCAGAGAGCGTGACTC-3' \\
\hline & R: 5'-TTGAACTGTACCACCGAGCC-3' \\
\hline \multirow[t]{2}{*}{ Egr1 } & F: 5'-GAGCACCTGACCACAGAGTC-3' \\
\hline & R: 5'-AAAGGGGTTCAGGCCACAAA-3' \\
\hline \multirow[t]{2}{*}{ Jun } & F: 5'-GCACCTCCGCGCCAAGAACT-3' \\
\hline & R: 5'-AAGCCСTCCTGCTCGTCGGT-3' \\
\hline \multirow[t]{2}{*}{$\mathrm{Nr} 2 \mathrm{f} 2$} & F: 5'-TGGAGAAGCTCAAGGCACTG-3' \\
\hline & R: 5'-AAGAGCTTTCCGAACCGTGT-3' \\
\hline \multirow[t]{2}{*}{ Rp/19 } & F: 5'-CTGAAGGTCAAAGGGAATGTG-3' \\
\hline & R: 5'-GGACAGAGTCTTGATGATCTC-3' \\
\hline
\end{tabular}

F, forward primer; $R$, reverse primer.

acquisition of fluorescence levels at the end of each extension step. Each amplification was performed in duplicate using four different samples from each treatment: control siRNA or siRNA against GATA4 (three times with GATA4MSS247225 and one time with GATA4MSS247223). PCR products were confirmed by analysis of melting curve, agarose-gel electrophoresis, and sequencing. Differences in mRNA levels between samples were quantified using relative quantification with external standards as previously described (Boulende Sab et al. 2011). PCR DNA fragments containing the genes of interest were used to generate the standard curves. The amount of DNA for the target and reference (Rp/19) in the unknown samples was calculated by the LightCycler Software 3.5 (Roche Diagnostics Canada) using the respective dilution curves. Means of data are reported in arbitrary units as the ratio of the level of target gene to the Rp/19 reference gene \pm s.E.M.

\section{Protein extraction and western blot}

Total protein extracts were obtained $48 \mathrm{~h}$ after siRNA transfection of MA-10 cells. The cells were washed twice with cold PBS, scraped, and pelleted at $4{ }^{\circ} \mathrm{C}$. The cells were lysed for $15 \mathrm{~min}$ on ice with $150 \mu \mathrm{l}$ of lysis buffer $(50 \mathrm{mM}$ Tris-HCl pH 7.4, $150 \mathrm{mM} \mathrm{NaCl}, 1 \mathrm{mM}$ EDTA, 0.5\% Igepal, and protease inhibitors). The cells were sonicated using a Branson sonifier 450 (Branson Ultrasonics, Danbury, CT, USA) for $30 \mathrm{~s}$ at two output control and constant duty cycle. The lysed cells were centrifuged for $10 \mathrm{~min}$ to pellet cellular debris.
The supernatants were collected and protein concentration was calculated by the Bradford method using Bio-Rad protein assay dye reagent (Bio-Rad). Western blotting was performed using MA-10 total cell extracts from both experimental conditions. The proteins were boiled for $10 \mathrm{~min}$ in a denaturing loading buffer and were separated by SDS-PAGE, transferred to Amersham Hybond-P membrane (GE Healthcare Life Sciences, Baie d'Urfe, Quebec, Canada), and immunodetected using antisera specific for GATA4 (goat polyclonal antibody, dilution 1:1000, cat. no. sc-1237x, Santa Cruz Biotechnologies), CYP11A1 (goat polyclonal antibody, 1:200 dilution, cat. no. sc-18043, Santa Cruz Biotechnologies), STAR (rabbit polyclonal antibody, 1:1000 dilution, cat. no. sc-25806, Santa Cruz Biotechnologies), or $\alpha$-TUBULIN (monoclonal mouse antibody, 1:10 000 dilution, cat. no. \#15168, Sigma-Aldrich). The membrane was blocked with 5\% skimmed milk, and primary and secondary antibodies were incubated for $1 \mathrm{~h}$ in $1 \%$ skimmed milk (5\% skimmed milk for $\alpha$-TUBULIN and its secondary antibody). Immunodetection was performed using HRP secondary antibodies and ECL Prime Western Blotting Detection Reagent (GE Healthcare Life Sciences) according to the manufacturer's instructions. The following secondary peroxidase antibodies were used: horse polyclonal anti-goat antibody (1:5000 dilution, cat. no. PI-9500, Vector Laboratories, Burlington, Ontario, Canada), goat polyclonal anti-rabbit antibody (1:10 000 dilution, cat. no. PI-1000, Vector Laboratories), and goat polyclonal anti-mouse antibody (1:20 000 dilution, cat. no. 115-035-003, Jackson ImmunoResearch Laboratories, Inc., West Grove, PA, USA). Densitometry was performed using ImageJ Software as described (http://lukemiller.org/index.php/2010/11/analyzing-gels-andwestern-blots-with-image-j/).

\section{Microarray analysis}

DNA microarray analyses were carried out with Affymetrix Mouse Gene 1.0 ST arrays. The chips were processed according to the Affymetrix standard protocol. In brief, total RNA (200 ng/sample) was labeled using the Affymetrix GeneChip WT cDNA Synthesis and Amplification Kit protocol, and hybridized to the arrays as described by the manufacturer (Affymetrix, Santa Clara, CA, USA). The cDNA hybridization cocktail was incubated overnight at $45^{\circ} \mathrm{C}$ with rotation in a hybridization oven. After $16 \mathrm{~h}$ of hybridization, the cocktail was removed and the arrays were washed and stained in an Affymetrix GeneChip fluidics station 450, according to the Affymetrix-recommended protocol (http://media.affymetrix. com/support/downloads/manuals/wt_sensetarget_label_ manual.pdf). The arrays were scanned using the Affymetrix GCS 3000 7G and the Gene-Chip Operating Software (Affymetrix) to produce the intensity files. Microarray hybridization was carried out at the Microarray Facility of the Centre de recherche du CHU de Quebec. Three independent RNA samples treated with Stealth RNAi Negative Control and three with Stealth RNAi molecules against GATA4 (one sample with GATA4MSS247223 and two with GATA4MSS247225) were analyzed by microarray; two different GATA4 siRNAs were used to minimize off-target effects (Jackson \& Linsley 2010). Analysis of microarray data and principal component analysis 
(PCA; Ringner 2008) were performed using Partek Software version 6.6 (Partek Inc., St Louis, MO, USA). Robust multiarray analysis (RMA) background correction and a logarithmic transformation were applied to data arrays. Differentially expressed genes were analyzed by t-test paired two-tailed, two-sample equal variance comparison between the groups treated with control siRNA or siRNA against GATA4. The complete list of genes modulated in response to GATA4 knockdown in MA-10 cells is presented in Supplementary File 1, see section on supplementary data given at the end of this article. Ingenuity interactive pathway analysis (IPA, Ingenuity Systems, www.ingenuity.com) was used to identify pathways and biological processes regulated by GATA4. The threshold value was fixed at 1.3 -fold change, the $P$ value $<0.05$, and a false discovery rate (FDR) $<0.25$ for IPA.

\section{Plasmids}

The -1.6 kb mice anti-Müllerian hormone receptor 2 (Amhr2)luciferase promoter construct was generously provided by Dr José Teixeira (Teixeira et al. 1999). The minimal - 33 bp mice Amhr2luciferase promoter was amplified by PCR from the longer $-1.6 \mathrm{~kb}$ sequence using the following primers - sense: 5'-CGCGAGCTCAGTTGGGGATTGAAGGCTTGG-3' and antisense: 5'-CGCAGATCTCGAGAAGGATGC-3'. The short - 33 bp Amhr2 promoter sequence was cloned into the $\mathrm{Xhol} / \mathrm{Sacl}$ sites of the same pGL3-Basic (Promega) luciferase backbone vector in which the longer $-1.6 \mathrm{~kb}$ Amhr2 promoter sequence was also cloned. Amhr2 promoter constructs containing mutated GATA motifs were obtained by site-directed mutagenesis using PfuUltra (Agilent, Santa Clara, CA, USA) with the following primers (mutations are in lower case) - sense: 5'-CTGATGATTGTGAGCTACCATGTGGTTGCTGG-3'; antisense: 5'-CCAGCAACCACATGgTAGCTCACAATCATCAG-3' and sense: 5'- GAGATTTCGTAGTCAATTACCACAGGGTTCTCAGC-3'; antisense: 5'- GCTGAGAACCCTGTGgTAATTGACTACGAAATCTC- $3^{\prime}$. The $-1.3 \mathrm{~kb}$ rat steroid $5 \alpha$-reductase 1 (Srd5a1) promoter sequence was amplified from rat genomic DNA and cloned into the BamHI/Kpnl site of a modified pxP1-luciferase promoterless reporter plasmid (Tremblay \& Viger 1999), with the following primers - sense: $5^{\prime}$-CGGGATCCCAACCCTGGCTGCTCTATAGC-3'; antisense: 5' - GGGGTACCGAGGTCGAGCAGTGTACTCC-3'. The Srd5a1-luciferase promoter construct containing a mutated GATA motif was obtained by site-directed mutagenesis using primers - sense: 5'-GATCTTGAGTTCCTGgTAGTAGTGCTCAAAGAGC-3'; antisense: 5'-GCTCTTTGAGCACTACTAcCAGGAACTCAAGATC$3^{\prime}$. The minimal -32 bp Srd5a1-luciferase promoter construct (Seenundun \& Robaire 2005) was generated by subcloning the following double-stranded oligonucleotide - sense: 5'-GATCCTTATATGAGGCTCCACTCGGACACCCGGGCATGGAGTACACTGCTCGACCTCGGTAC -3'; antisense: 5'-CGAGGTCGAGCAGTGTACTCCATGCCCGGGTGTCCGAGTGGAGCCTCATATAAG-3' - into the modified pxP1-luciferase reporter plasmid. Luciferase reporter constructs containing the mouse Star promoter ( $-902 \mathrm{bp},-902$ bp containing a mutation of the GATA element at $-63 \mathrm{bp}$, and the minimal $-43 \mathrm{bp}$ sequence) as well as the GATA4 expression plasmid have been described previously (Tremblay \& Viger 2001, Martin etal. 2012).

\section{Cell culture, transfections, and luciferase promoter assays}

Mouse MA-10 Leydig cells were kindly provided by Dr Ascoli (1981). MA-10 cells were cultured in DMEM/F12 supplemented with $5 \%$ fetal bovine serum and $2.5 \%$ horse serum. The day before transfection $1.5 \times 10^{5} \mathrm{MA}-10$ cells were plated in 24-well plates by the calcium phosphate method (Jordan \& Wurm 2004). The amount of promoter-luciferase reporter DNA was kept at $500 \mathrm{ng} /$ well; GATA4 expression vector was used at $50 \mathrm{ng} /$ well and pSP64 (Promega) was used as carrier to keep the final concentration of DNA at $1.5 \mu \mathrm{g} /$ well. The cell media was changed the day after the transfection and cells were lysed 1 day later by adding $50 \mu$ of lysis buffer $(100 \mathrm{mM}$ Tris-Hcl ( $\mathrm{pH} 8), 0.5 \%$ Igepal, and $5 \mathrm{mM}$ dithiothreithol) directly to the cells. The lysate was collected and assayed for luciferase activity using a Luminoskan Ascent luminometer (Thermo, Milford, MA, USA). For all experiments, the data reported represent the fold change in promoter activity \pm s.E.M. of at least four experiments, each done in triplicate.

\section{Progesterone ELISA}

A progesterone ELISA was performed using MA-10 growth media from both experimental conditions (treated with control siRNA or GATA4 siRNA). MA-10 cells were plated in 24-well plates and transfected (at 50-60\% confluence) for $24 \mathrm{~h}$ with $150 \mathrm{nM}$ siRNAs. Two days after transfection, cells were washed and cultivated for $4 \mathrm{~h}$ in the media without serum with vehicle (DMSO) or $10 \mu \mathrm{M}$ forskolin (Sigma) and $0.5 \mathrm{mM}$ IBMX (Sigma). The media was collected and progesterone was measured using a progesterone EIA Kit (Cayman Chemical, cat. no. 582601, Ann Arbor, MI, USA) according to the manufacturer's instructions. The samples treated with DMSO were diluted 1:20 and forskolin/IBMX-stimulated samples were diluted 1:60.

\section{Statistical analyses}

A Student's t-test paired two-tailed comparison was used to detect significant differences between control and treated groups; $P<0.05$ was considered significant. All statistical analyses were done using GraphPad Prism 5 (GraphPad Software, Inc., La Jolla, CA, USA).

\section{Results}

To identify GATA4-regulated genes in the Leydig cell lineage, we performed a microarray screening analysis of MA-10 cells in which Gata4 expression was decreased using an siRNA-mediated knockdown strategy. MA-10 cells are an ideal model to use because unlike other testicular somatic cells (reviewed in Viger et al. (2008)), they are known to contain almost exclusively GATA4 protein (Tremblay \& Viger 2003b). MA-10 cells were transiently transfected with siRNAs that targeted two different regions of the Gata4 coding sequence. In both cases, the siRNAs achieved significant inhibition at the level of Gata4 mRNA (Fig. 1A) and 


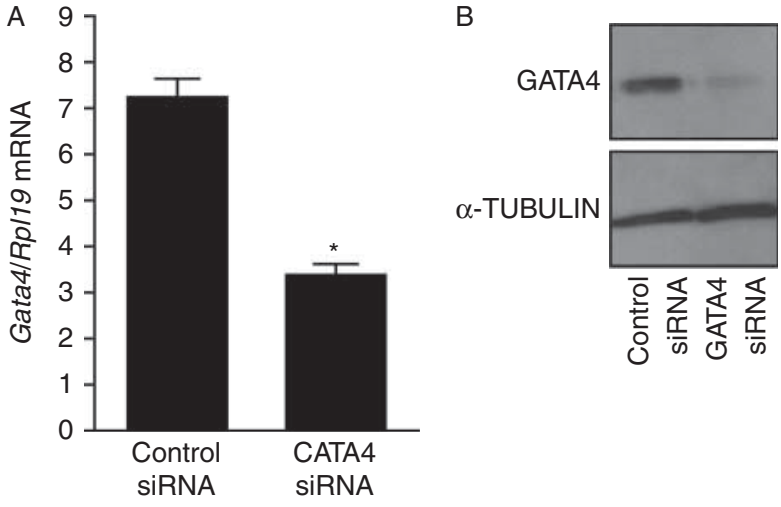

Figure 1 Knockdown of Gata4 expression in MA-10 Leydig cells. MA-10 cells were transiently transfected with either control siRNA or siRNA against GATA4. (A) Global detection of Gata4 mRNAs, using oligonucleotide primers corresponding to the Gata4 coding region, was measured in four independent knockdown experiments $(n=4)$ by realtime quantitative PCR (qPCR). Quantitative data were normalized using the housekeeping RpL19 gene and expressed as the mean \pm s.E.M. An asterisk indicates a significant difference between the control and GATA4 siRNA groups $(P<0.05)$. (B) Western blotting analysis was performed using MA-10 total cell extracts from both experimental conditions. Proteins were separated by SDS-PAGE, transferred to PVDF membrane, and immunodetected using antisera specific for GATA4 or $\alpha$-TUBULIN (used as loading control).

GATA4 protein (Fig. 1B). $\alpha$-tubulin was used as a control in the western blotting analysis to indicate that the GATA4 siRNA did not cause a general decrease in protein synthesis. Total cellular RNA was prepared from both GATA4 siRNA and control siRNA-treated MA-10 cells and then hybridized to Affymetrix Mouse Gene 1.0 ST arrays to identify global changes in genes under GATA4 control. RMA background correction and a logarithmic transformation were applied to data arrays, and differentially expressed genes were identified by $t$-test paired two-tailed two-sample equal variance comparisons. PCA of all normalized array data was performed to first analyze the RNA profiles of MA-10 cells treated with the control vs GATA4 siRNAs. As shown in Fig. 2, the control siRNA and GATA4 siRNA groups from three separate experiments clustered separately, indicating that the control and GATA4 siRNA treatments produced distinct, yet reproducible RNA populations. The complete list of MA-10 cell genes modulated in response to GATA4 knockdown, and expressed as fold change in comparison to the control siRNA, is provided in Supplementary File 1.

Our microarray analysis yielded 335 upregulated and 374 downregulated genes with a fold change of at least 1.3 , a $P$ value of $<0.05$, and an FDR $<0.25$. The data were analyzed using Ingenuity IPA (interactive pathway analysis of complex 'omics data' version 16542223) to identify key pathways dependent on GATA4. Analysis according to biological function (used to predict the effect of gene expression changes in the dataset on biological processes) identified several processes that were modulated (z-score) in response to GATA4 knockdown in MA-10 cells. These included the conversion of hormone, metabolism of membrane lipid derivative, accumulation and transport of cholesterol ester, conversion of pregnenolone, synthesis of pregnenolone, secretion of steroid hormone, synthesis of androgen, and steroidogenesis (Supplementary File 2, see section on supplementary data given at the end of this article).

Table 2 gives a selected list of genes that were specifically upregulated in response to GATA4 knockdown in MA-10 cells. The two most highly upregulated genes were integrin beta 8 (Itgb8; 4.03 -fold) and versican (Vcan, 3.32-fold), which encode for proteins involved in cell-cell and cell-extracellular matrix interactions. Significantly upregulated genes also included SMT3 suppressor of mif two homolog 3 (Sumo3, 1.87-fold) involved in protein posttranslational modification, and the immediate early genes early growth response 1 (Egr1, 1.63 -fold) and JUN oncogene (Jun, 1.62-fold). The list of upregulated genes also identified several genes involved in cell signaling such as calcium/calmodulin-dependent protein kinase kinase 1 (Camkk1) and Smad family member 5 (Smad5, 1.53-fold), as well as several genes

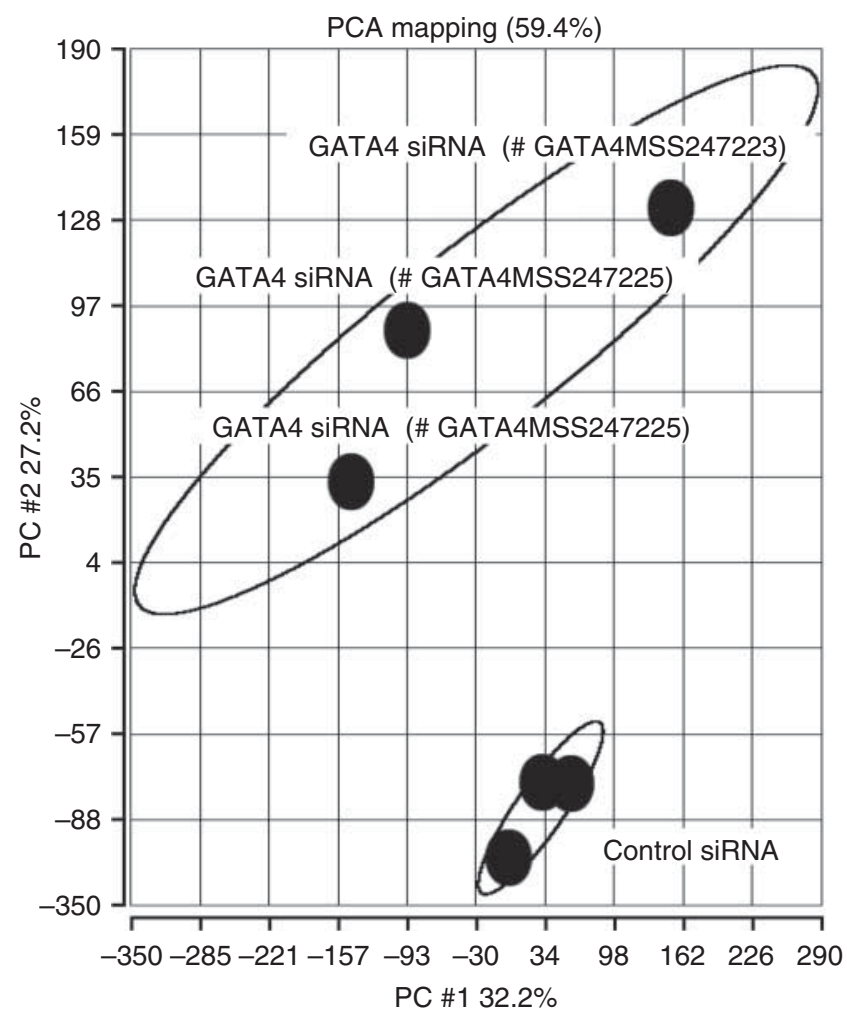

Figure 2 RNA profile in MA-10 cells following GATA4 knockdown. Principal component analysis (PCA) of all normalized array data. Each point represents a hybridized sample: samples treated with siRNA against Gata4 transcript sequence and samples treated with control siRNA. $X$-axis, first principal component (PC1); $y$-axis, second principal component (PC2). PCA was done using Partek Software 6.6. 
Table 2 Selected list of genes upregulated in Affymetrix Gene 1.0 ST Array following GATA4 knockdown in MA-10 Leydig cells.

\begin{tabular}{|c|c|c|c|c|c|}
\hline $\begin{array}{l}\text { Transcript } \\
\text { cluster ID }\end{array}$ & Gene symbol & Description & $P$ value & $\begin{array}{l}\text { False discovery } \\
\text { rate }\end{array}$ & Fold change \\
\hline 10403229 & $\operatorname{ltg} b 8$ & Integrin beta 8 & 0.00037 & 0.074 & 4.03 \\
\hline 10410931 & Vcan & Versican & 0.0014 & 0.112 & 3.32 \\
\hline 10364287 & Sumo3 & SMT3 suppressor of mif two 3 homolog 3 (yeast) & 0.0001 & 0.061 & 1.87 \\
\hline 10378253 & Camkk1 & $\begin{array}{l}\text { Calcium/calmodulin-dependent protein kinase } \\
\text { kinase } 1\end{array}$ & 0.0055 & 0.164 & 1.86 \\
\hline 10454782 & Egr1 & Early growth response 1 & 0.0006 & 0.084 & 1.63 \\
\hline 10514466 & Jun & Jun oncogene & 0.057 & 0.413 & 1.62 \\
\hline 10564527 & $\mathrm{Nr} 2 \mathrm{f} 2$ & Nuclear receptor subfamily 2 , group $F$, member 2 & 0.0009 & 0.096 & 1.61 \\
\hline 10490731 & Sox18 & SRY-box containing gene 18 & 0.0055 & 0.172 & 1.60 \\
\hline 10405605 & Smad5 & $\begin{array}{l}\text { Mothers against decapentaplegic homolog } 5 \\
\text { (drosophila) }\end{array}$ & 0.0016 & 0.112 & 1.53 \\
\hline 10482772 & $\mathrm{Nr} 4 \mathrm{a} 2$ & Nuclear receptor subfamily 4 , group A, member 2 & 0.004 & 0.078 & 1.43 \\
\hline
\end{tabular}

coding for transcription factors including COUPTFII (Nr2f2, 1.61-fold), NURR1 (Nr4a2, 1.43-fold), and SRYbox containing gene 18 (Sox18; 1.6 -fold). A subset of the upregulated genes was validated by qPCR (Fig. 3).

Many genes crucial to MA-10 cell function were found to be downregulated in response to GATA4 depletion. These included Gata4 itself $(-1.86$-fold), which was targeted in the siRNA knockdown and also Gata1 (-1.99-fold), another GATA family member whose mRNA is known to be present in MA-10 cells (Zhang et al. 2002), and whose expression is regulated by GATA factors (reviewed in Kobayashi \& Yamamoto (2007)). Interestingly, however, many downregulated genes were those that encode for multiple components of the cholesterol transport, cholesterol biosynthesis, and steroidogenic pathways (Table 3). Genes involved in cholesterol transport included scavenger receptor B1 (Scarb1, -1.74-fold) and LDL receptor ( $L d l r$, -1.48 fold), which code for proteins required for receptormediated uptake of cholesterol bound to HDL and LDL respectively. The effect on cholesterol metabolism was not limited to cholesterol transport/bioavailability as we observed equally important decreases in the expression of several genes involved in de novo cholesterol biosynthesis; these included sterol-C5-desaturase (Sc5d, - 1.51-fold), lanosterol $14 \alpha$-demethylase (Cyp51, -1.32-fold), and mevalonate decarboxylase (Mvd, -1.31-fold). The genes encoding sterol O-acyltransferase (Soat1, -1.33 -fold), which regulates the level of intracellular free cholesterol by promoting the formation of esterified cholesterol for storage in lipid droplets, and sterol regulatory element binding protein (SREBP) cleavage activating protein (Scap, -1.37 -fold), an important sensor of cholesterol in the endoplasmic reticulum, were also significantly downregulated.

Gene set enrichment analysis (GSEA version 2.0.13) pathway analysis (using gene set c2.all.v4.0.) was performed on the array data. The reactome steroid hormones pathway was one of the most downregulated pathways (in the top ten) and therefore identifies steroid metabolism as a major process in MA-10 cells that is critically dependent on the presence of GATA4
(Supplementary Files 3 and 4, see section on supplementary data given at the end of this article). Of the genes identified, Star was at the top of the list of genes with reduced expression in GATA4-depleted MA-10 cells $(-3.65$-fold). Other important downregulated genes associated with the regulation of steroidogenesis included members of the $3 \beta-\mathrm{HSD}$ family ( Hsd3b6 and $H s d 3 b 1 ;-2.65-$ and -1.97 -fold respectively), anti-Müllerian hormone type 2 receptor (Amhr2, -2.31-fold), glutathione $S$-transferase alpha 3 (Gsta3,
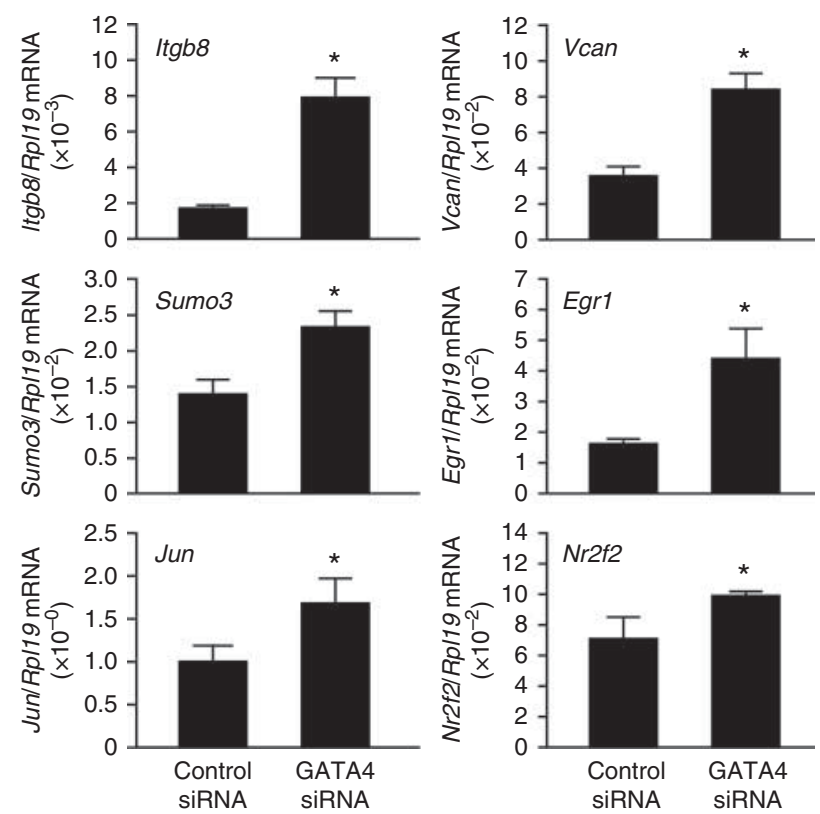

Figure 3 Quantitative PCR validation of upregulated targets genes identified in the microarray analysis following GATA4 knockdown. Global detection of the different genes of interest, using oligonucleotide primers corresponding to the respective coding regions, was measured in four different independent experiments $(n=4)$ by qPCR. Quantitative data were normalized using the housekeeping Rp/19 gene and expressed as the mean \pm s.E.M. Asterisks indicate significant differences between the control and GATA4 siRNA groups $(P<0.05)$. Itgb8, integrin beta 8; Vcan, versican; Sumo3, g SMT3 suppressor of mif two 3 homolog 3; Egr1, early growth response 1; Jun, jun proto-oncogene; Nr2f2, nuclear receptor subfamily 2, group F, member 2 . 
Table 3 Selected list of genes downregulated in Affymetrix Gene 1.0 ST array following GATA4 knockdown in MA-10 Leydig cells.

\begin{tabular}{|c|c|c|c|c|c|}
\hline $\begin{array}{l}\text { Transcript } \\
\text { cluster ID }\end{array}$ & Gene symbol & Description & $P$ value & $\begin{array}{c}\text { False } \\
\text { discovery rate }\end{array}$ & Fold change \\
\hline 10345065 & Gsta3 & Glutathione $S$-transferase, alpha 3 & 0.0003 & 0.070 & -3.96 \\
\hline 10571054 & Star & Steroidogenic acute regulatory protein & 0.0002 & 0.067 & -3.65 \\
\hline 10500559 & Hsd3b6 & $\begin{array}{l}\text { Hydroxy-delta-5-steroid dehydrogenase, } 3 \text { beta- and } \\
\text { steroid delta-isomerase } 6\end{array}$ & 0.0019 & 0.121 & -2.65 \\
\hline 10589994 & Eomes & Eomesodermin homolog (Xenopus laevis) & 0.0005 & 0.081 & -2.57 \\
\hline 10427222 & Amhr2 & Anti-Müllerian hormone type 2 receptor & 0.0013 & 0.107 & -2.31 \\
\hline 10410452 & Srd5a1 & Steroid 5 alpha-reductase 1 & 0.0036 & 0.155 & -2.23 \\
\hline 10460400 & $P_{C X}$ & Pyruvate carboxylase & 0.0001 & 0.061 & -2.05 \\
\hline 10603417 & Gata1 & GATA binding protein 1 & $1.94 \times 10^{-5}$ & 0.060 & -1.99 \\
\hline 10500565 & Hsd3b1 & $\begin{array}{l}\text { Hydroxy-delta-5-steroid dehydrogenase, } 3 \text { beta- and } \\
\text { steroid delta-isomerase } 1\end{array}$ & 0.0010 & 0.098 & -1.97 \\
\hline 10420747 & Gata4 & GATA-binding protein 4 & 0.0013 & 0.109 & -1.86 \\
\hline 10347669 & Inha & Inhibin alpha & $6.94 \times 10^{-5}$ & 0.060 & -1.76 \\
\hline 10533929 & Scarb1 & Scavenger receptor class $\mathrm{B}$, member 1 & $1.70 \times 10^{-4}$ & 0.065 & -1.74 \\
\hline 10366052 & Kitl & Kit ligand & 0.0119 & 0.223 & -1.56 \\
\hline 10592585 & $S c 5 d$ & Sterol-C5-desaturase & 0.0054 & 0.171 & -1.51 \\
\hline 10569319 & Ctsd & Cathepsin D & $4.16 \times 10^{-5}$ & 0.060 & -1.49 \\
\hline 10583732 & Ldlr & LDL receptor & $4.63 \times 10^{-4}$ & 0.078 & -1.48 \\
\hline 10589511 & Scap & SREBF chaperone & 0.0017 & 0.116 & -1.37 \\
\hline 10359161 & Soat1 & Sterol $O$-acyltransferase 1 & 0.0016 & 0.115 & -1.33 \\
\hline 10527920 & Cур51 & Cytochrome P450, family 51 & 0.0034 & 0.152 & -1.32 \\
\hline 10582310 & Mvd & Mevalonate (diphospho) decarboxylase & 0.00017 & 0.066 & -1.31 \\
\hline 10403743 & Inhba & Inhibin beta-A & 0.0081 & 0.197 & -1.30 \\
\hline 10585794 & Cyp11a1 & Cytochrome P450, family 11 , subfamily a, polypeptide 1 & 0.0226 & 0.289 & -1.28 \\
\hline
\end{tabular}

-3.96-fold), and steroid 5 $\alpha$-reductase type 1 (Srd5a1, -2.23 -fold). Other non-steroidogenic targets found to be significantly downregulated included the T-box transcription factor eomesdermin (Eomes, -2.57 -fold), pyruvate carboxylase $(P C X,-2.05$-fold) involved in energy metabolism, kit ligand (Kitl, -1.56 -fold), the protease cathepsin D (Ctsd, -1.49-fold), and two subunits of the inhibin hormone family (Inha and Inba; -1.76 and -1.3 -fold respectively).

A subset of genes involved in steroidogenesis that were found to be significantly downregulated from the microarray analysis was validated by qPCR (Fig. 4). All genes examined exhibited the same pattern of significantly reduced expression as was observed from the Affymetrix Gene Chip screen, indicating that these targets are very sensitive to modulation of GATA4 levels in the MA-10 cell line. The downregulation of gene expression in response to GATA4 was further confirmed at the protein level by western blotting analysis; two representative targets, CYP11A1 and STAR, are shown in Fig. 5. Quantitation of the western blots showed that the decreases observed at the mRNA level were extended to the protein level. The significant drop in STAR (Fig. 5B), and especially CYP11A1 (Fig. 5A) protein level, was likely an important contributing factor to the crippling effect that GATA4 knockdown had on the ability of MA-10 cells to produce progesterone. As previously mentioned, two different GATA4 siRNAs were used in the microarray and qPCR analyses to reduce the likelihood of the observed changes in gene expression being due to off-target effects. To further demonstrate that the GATA4 siRNAs were indeed targeting GATA4dependent functions, we transfected MA-10 cells with control siRNA or siRNA against GATA4 along with either a -902 bp Star-luciferase reporter, a highly GATA-sensitive reporter (Tremblay \& Viger 2001), or a similar reporter harboring a mutated GATA (GATA to GGTA) responsive element. As shown in Fig. 6, only the WT Star promoter (containing an intact GATA motif) exhibited a significant decrease in activity in a context of siRNA-mediated Gata4 inhibition. Given the dramatic reductions in gene expression at several levels of the steroidogenic pathway, we expected GATA4 knockdown to severely compromise the ability of MA-10 cells to produce progesterone, their main steroid product (Ascoli 1981). Indeed as shown in Fig. 7, transfection of MA-10 cells under the same conditions used to generate the microarray results, markedly reduced the capacity of the cells to produce progesterone. This decrease was observed under basal conditions and in response to forskolin treatment, which mimics gonadotropin-stimulation and dramatically upregulates the amount of progesterone produced by the cells.

Genes modulated in response to GATA4 knockdown may either be direct targets for GATA4 transcriptional regulation at the level of the corresponding promoter regulatory sequences or indirectly regulated by GATA4. For some of the genes we identified, such as Star, Cyp11a1, and Inha, direct transcriptional by GATA4 is very likely given that in vitro transcription studies have previously identified these genes as potential GATA4regulation targets (Silverman et al. 1999, Wooton-Kee \& Clark 2000, Tremblay \& Viger 2001, Robert et al. 2006, Sher et al. 2007). Our microarray analysis, however, identified additional novel steroidogenic targets ( $\mathrm{Srd5a} 1$ and Amhr2) that may also be direct transcriptional 

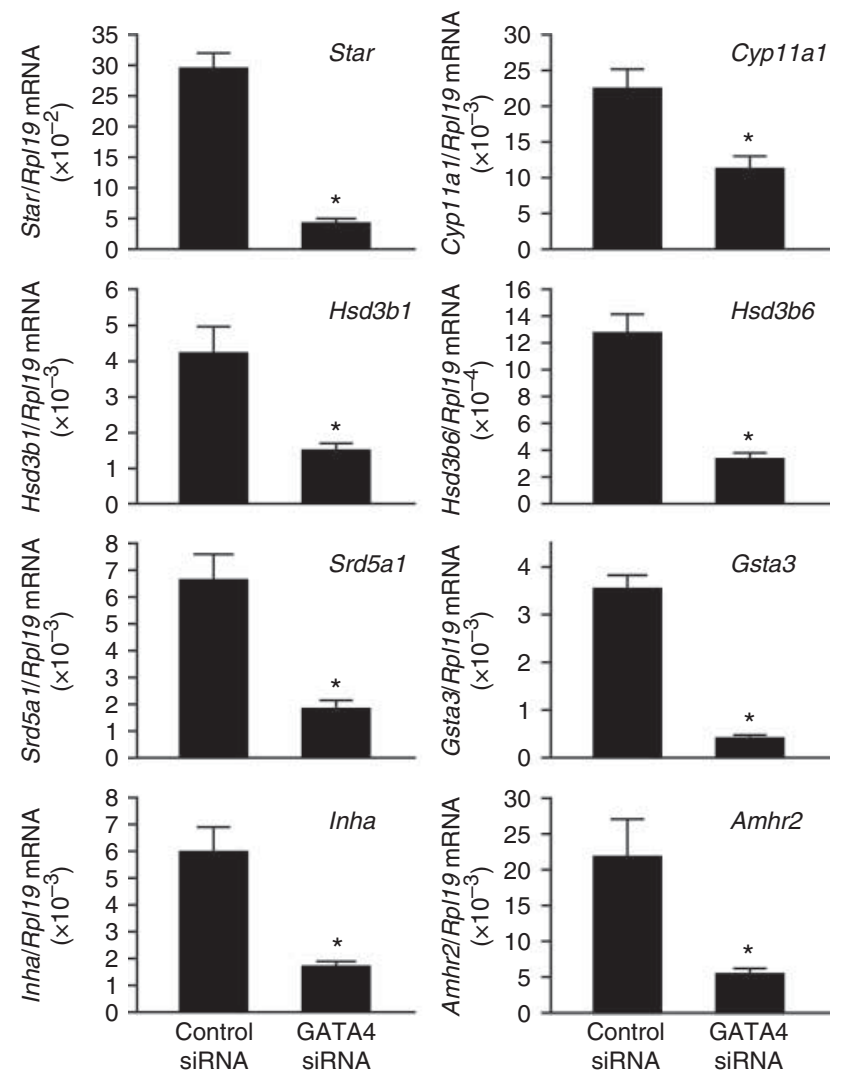

Figure 4 Quantitative PCR validation of steroidogenic targets genes identified in the microarray analysis following GATA4 knockdown. Global detection of the different genes of interest, using oligonucleotide primers corresponding to the respective coding regions, was measured in four different independent experiments $(n=4)$ by qPCR. Quantitative data were normalized using the housekeeping Rp/19 gene and expressed as the mean \pm s.E.M. Asterisks indicate significant differences between the control and GATA4 siRNA groups $(P<0.05)$. Amhr2, antiMüllerian hormone type 2 receptor; Cyp11a1, cholesterol side-chain cleavage enzyme; Gsta3, glutathione S-transferase alpha 3; Hsd3b1, hydroxy-delta-5-steroid dehydrogenase, 3 beta- and steroid deltaisomerase $1 ; H s d 3 b 6$, hydroxy-delta-5-steroid dehydrogenase, 3 betaand steroid delta-isomerase 6; Inha, inhibin alpha; Srd5a1, steroid 5 alpha-reductase 1; Star, steroidogenic acute regulatory protein.

targets for GATA4 in Leydig cells. To test this possibility, the -1.3 and $-1.6 \mathrm{~kb}$ proximal promoter regions of the rat Srd5a1 and mouse Amhr2 genes, respectively, were transfected in MA-10 cells to assess their responsiveness to GATA4 stimulation (Fig. 8). The mouse Amhr2 proximal promoter has two perfect GATA motifs at nucleotide positions $-1172 /-1167 \mathrm{bp}$ and $-221 /$ -216 bp, whereas the rat Srda51 promoter has a single consensus GATA element at position -1079/-1074 bp and two imperfect motifs at nucleotide positions $-1036 /-1030 \mathrm{bp}$ and $-685 /-679 \mathrm{bp}$. In these experiments, the -902 bp mouse Star promoter (Fig. 8A), a previously described GATA4 target (Tremblay \& Viger 2001), was used as a positive control. When transfected in MA-10 cells, the Srd5a1 and Amhr2 promoters both showed a significant activation in response to GATA4 transactivation in comparison to their respective minimal promoters lacking GATA-responsive elements (Fig. 8B and C), suggesting that they may also be direct targets for GATA4. This was assessed by testing the GATA responsiveness of the corresponding promoter constructs containing mutated GATA motifs. Mutation of the Amhr2 promoter proximal GATA motif $(-1172 /-1167 \mathrm{bp})$ attenuated GATA-mediated activation indicating that the Amhr2 gene can by a direct target for GATA4. However, activation of the Srd5a1 promoter is most likely indirect or triggered by its imperfect GATA motifs because mutation of the lone consensus GATA binding motif had no significant effect.

\section{Discussion}

The GATA4 transcription factor plays a pivotal role in the development and function of multiple tissues originating from both mesoderm and endoderm. Among these

A
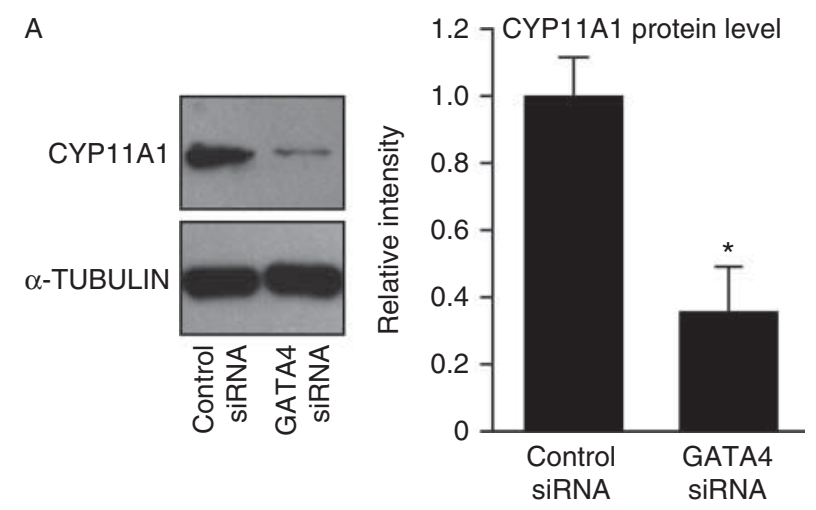

B
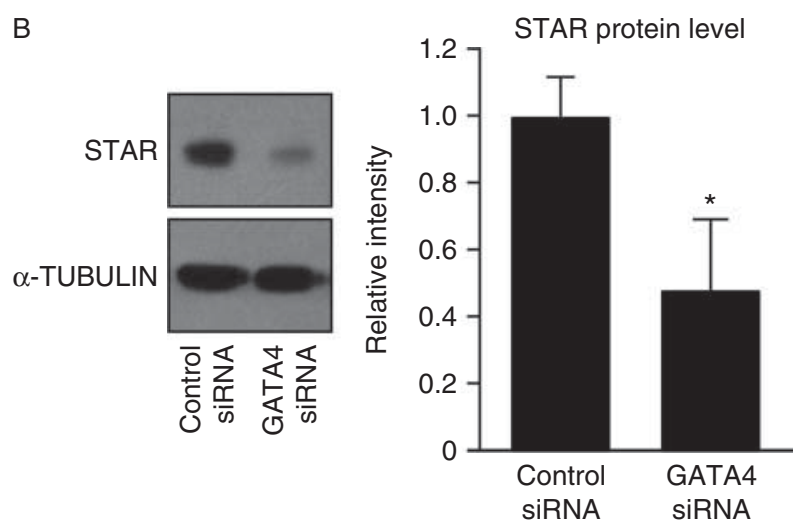

Figure 5 GATA4 knockdown in MA-10 cells decreases STAR and CYP11A protein levels. Western blotting analysis was performed using MA-10 total cell extracts from both experimental conditions as indicated. Proteins were separated by SDS-PAGE, transferred to PVDF membrane, and immunodetected using antisera specific for (A) CYP11A1 or (B) STAR. Alpha-TUBULIN was used as a loading control. Densitometry was performed using ImageJ Software. Quantitative data indicate the average of four experiments \pm s.E.M. Asterisks indicate significant differences between the control and GATA4 siRNA groups $(P<0.05)$. 


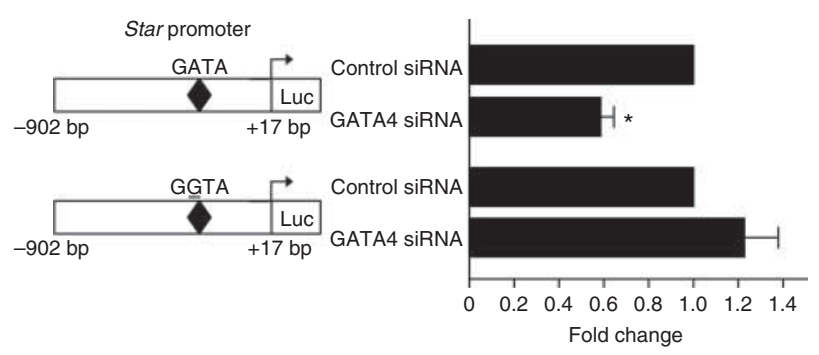

Figure 6 Knockdown of endogenous Gata4 expression in MA-10 cells diminishes Star promoter activity. MA-10 cells were transfected with the -902 bp mouse Star promoter construct with either intact GATA motifs or carrying a mutation in the GATA binding site (GATA to GGTA). Cells then received either control siRNA or siRNA specific for GATA4. Promoter activities are expressed as fold change relative to the control siRNA group. The results report the means of four experiments \pm s.E.M. An asterisk indicates a significant difference between the control and GATA4 siRNA groups $(P<0.05)$. Note that GATA4 knockdown only affects the activity of the Star promoter construct containing an intact GATA motif.

tissues, Gata4 is highly expressed in the somatic cell lineages of gonads in both sexes from the onset of gonadal morphogenesis through adulthood (reviewed in Viger et al. (2008) and Zaytouni et al. (2011)). Consistent with this expression pattern, different genetic mouse models have begun to illuminate the complex and essential roles played by this transcription factor in the very first steps of gonadal development and later, for male and female fertility (Kyrönlahti et al. 2011a,b, Manuylov et al. 2011, Bennett et al. 2012, Efimenko et al. 2013, Hu et al. 2013, Tevosian 2014). While these studies clearly established the essential nature of GATA4 in reproduction, understanding how GATA4 accomplishes these tasks, i.e., identifying its target genes and thus its mechanism of action, remains incomplete. In this study, we took advantage of the MA-10 Leydig cell line and an siRNA knockdown strategy to generate cells that are deficient in GATA4. Microarray analysis of these cells allowed us to show that the essential role of GATA4 in male reproductive function is likely achieved in part by its important contribution to the expression of several key genes involved in Leydig cell cholesterol metabolism and steroidogenesis.

While GATA4 has long been proposed to be a key regulator of steroidogenesis, formal proof is still lacking. Early insights into this role arose from the in vitro characterization of promoters of steroidogenic genes that GATA4 has been proposed to regulate (reviewed in Tremblay \& Viger (2003a), Viger et al. (2004 and 2008), King \& LaVoie (2012), Bouchard et al. (2005), Kwintkiewicz et al. (2007), Sher et al. (2007), Shi et al. (2009) and Shih et al. (2011)). To date, some supporting evidence for the potential in vivo requirement of GATA4 in steroidogenesis has come from conditional Gata4knockout mice studies in the ovary. Kyrönlahti et al. (2011b) were the first to report that gonadotropinstimulated ovaries from heterozygous mice carrying a single Gata4 null allele, or from mice in which Gata4 was deleted using an Amhr2-Cre driver, expressed less Star, Cyp11a1, and Cyp19a1 mRNA. It remained unclear, however, whether this decrease was due to downregulated transcription of the corresponding genes or whether it was due to the presence of fewer maturing follicles. Moreover, this model did not provide insights into GATA4 in Leydig cells as the Amhr2-driven Cre did not eliminate Gata4 expression in the testicular interstitium (Kyrönlahti etal. 2011a). In another study, Bennett et al. (2012) showed that conditional inactivation of Gata4, and especially Gata4 and Gata6 in the ovary, leads to decreased Cyp11a1 and Cyp19a1 expression. But again, it was unclear whether these changes were a consequence of decreased gene expression or a reflection of disrupted folliculogenesis. By contrast, our present result using GATA4-depleted MA-10 cells confirms that GATA4 is a key regulator of Star and Cyp11a1 expression in Leydig cells. Interestingly, our identification of genes modulated in response to GATA4 knockdown in MA-10 cells was not limited to these two steroidogenic targets. We also observed a significant decrease in other components of the steroidogenic pathway including two $3 \beta$-HSD isoforms ( Hsd3b1 and Hsd3b6), as well as a dramatic decrease in expression of Gsta3 that encodes a glutathione transferase that catalyzes obligatory double-bond isomerizations of steroid precursors, leading to both progesterone and testosterone formation in steroidogenic tissues (Johansson \& Mannervik 2001, Raffalli-Mathieu et al. 2008, Matsumura et al. 2013). These results therefore support a role for GATA4, much like it has been described for NR5A1 (Parker et al. 2002), as a transcriptional regulator that sits at the top of the steroidogenic program in Leydig cells.

Mouse genetic models offering direct insights into the contribution of GATA4 to steroidogenic gene expression in the testis have been difficult to interpret because of the
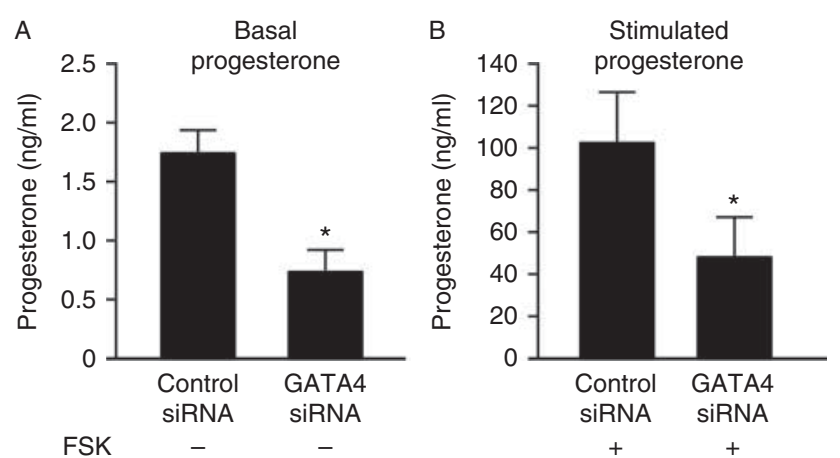

Figure 7 GATA4 knockdown attenuates (A) basal and hormonestimulated (B) steroidogenesis in MA-10 cells. Accumulation of progesterone in serum free media was measured by ELISA after $4 \mathrm{~h}$ treatment with or without forskolin (FSK). Results indicate the means of four independent experiments expressed as nano gram of progesterone per milliliter of media \pm S.E.M. Asterisks indicate significant differences between the control and GATA4 siRNA groups $(P<0.05)$. 
A
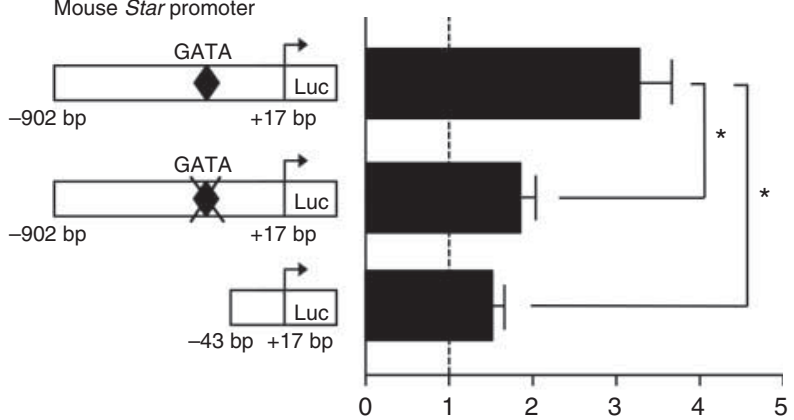

B
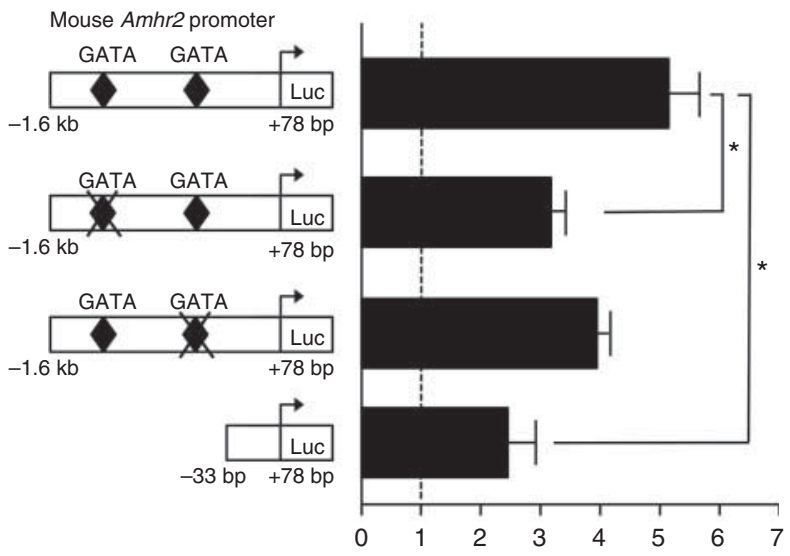

C
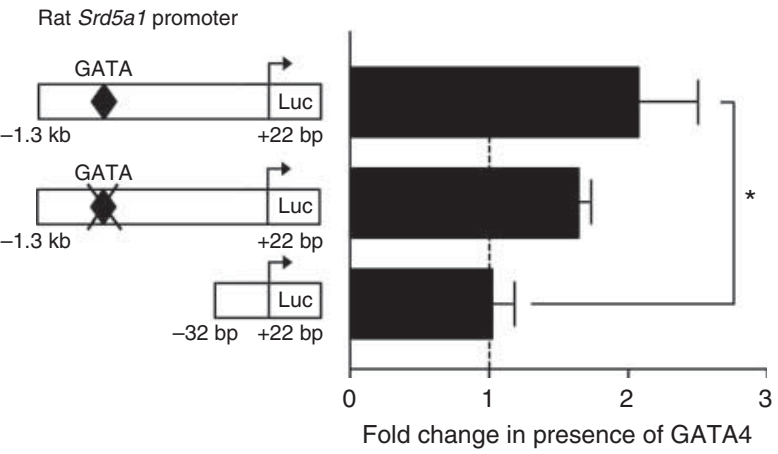

Figure 8 GATA4 directly activates the promoters of newly identified GATA4-regulated target genes in MA-10 Leydig cells. MA-10 cells were transfected with the (A) -902 bp Star promoter-luciferase reporter, a known GATA4 target (Tremblay \& Viger 2001), as well promoterluciferase sequences for (B) the mouse Amhr2 (-1.6 kb), and (C) rat Srd5a1 $(-1.3 \mathrm{~kb})$ genes, two new GATA4 targets identified through the GATA4 knockdown analysis. Matching minimal promoter sequences (lacking GATA motifs), or promoter sequences containing mutated GATA consensus motifs, were generated to evaluate the direct GATA responsiveness of the promoters. All transfections were done in the presence of 50 ng of a GATA4 expression plasmid. Promoter activities are reported as fold change elicited by the presence of GATA4; the dotted line indicates the baseline value of 1 (no change). Data report the means of four independent \pm s.E.M. Asterisks indicate significant differences $(P<0.05)$.

lack of reliable Cre-drivers allowing specific Gata4 gene deletion solely in Leydig cells, especially in the mature testis. Nonetheless, Manuylov et al. (2011) have described the testicular phenotype of mice where Gata4 was excised in both Leydig and Sertoli cells early during fetal development using Cre recombinase driven by Nr5a1 regulatory sequences (GATA4 ${ }^{\mathrm{SF}} \mathrm{XY}$ mice). While these mice exhibit profound defects in cord morphogenesis due to a disruption of Sertoli cell expression of Dmrt1, GATA4 ${ }^{\mathrm{SF}} \mathrm{XY}$ mice were also described as being undervirilized males with partially descended testes, hypoplastic penis, mammary teats, and a relatively shorter anogenital distance compared with their control counterparts (Manuylov et al. 2011). Cumulatively, these features are suggestive of decreased androgen exposure or androgen action during fetal development. Our present data showing an important role for GATA4 in MA-10 cell Leydig cell gene expression and steroid production supports these observations.

In addition to Star and Cyp11a1, our microarray analysis of MA-10 cells with reduced Gata4 expression identified other interesting downregulated targets associated with steroidogenesis. As mentioned previously, this included two 3ß-HSDs, Hsd3b1 and Hsd3b6, that encode essential enzymes required for progesterone production in steroidogenic tissues (reviewed in Simard et al. (2005)). In agreement with this finding, we have previously shown the promoter of the HSD3B2 gene, the human equivalent of the mouse Hsd3b1 gene, to be highly upregulated in response to GATA4 transactivation, especially in cooperation with the nuclear receptor NR5A1 (Martin et al. 2005). GATA4 has also been reported to be required for placental-specific activity of the promoter of the HSD3B1 gene (Peng et al. 2004), the human equivalent of the rodent $H s d 3 b 6$ gene. Apart from classical regulators of steroidogenesis, GATA4-deficient MA-10 cells also expressed less Amhr $2 \mathrm{mRNA}$, encoding the type 2 receptor for anti-Müllerian hormone and Srd5a1 mRNA, encoding one of the three $5 \alpha$-reductase isoforms involved in the production of $5 \alpha$-reduced $\mathrm{C}-19$ and $\mathrm{C}-21$ steroids (Azzouni et al. 2012). The AMH/AMHRII system has profound effects on Leydig cell physiology (Teixeira et al. 2001). Activation of this pathway blocks Leydig cell differentiation and represses steroidogenesis, especially at the level of CYP17 (Racine et al. 1998). We showed that the rat -1.6 Amhr2 promoter sequence, which contains two consensus GATA motifs, can by activated by GATA4 in MA-10 cells (Fig. 8B). Others have reported that the Amhr2 promoter is also regulated by NR5A1 and WT1 (Teixeira et al. 1999, Hossain \& Saunders 2003, Klattig et al. 2007). Interestingly, we have shown these two factors synergize with GATA4 on multiple gonadal promoters including Sry, Cyp19a1, HSD3B2, and Inha (Tremblay \& Viger 2001, Bouchard et al. 2005, Martin et al. 2005, Miyamoto et al. 2008). A similar regulation might therefore also exist at the level of the Amhr2 promoter in Leydig cells. Steroid $5 \alpha$-reductase type 1 is most prominently expressed in prostate, skin, liver, and sebaceous glands where it converts testosterone to the more potent androgen, $5 \alpha$-dihydrotestosterone (DHT; Azzouni et al. 2012). It is also found in Leydig cells, especially fetal Leydig cells and 
progenitor and immature adult Leydig cells in rodents (Viger \& Robaire 1995). Interestingly, the Srd5a1 gene was markedly downregulated in GATA4-deficient MA- 10 cells (Fig. 4), and its proximal promoter region could be directly transactivated by GATA4 (Fig. 8). DHT has been reported to be important for the testosterone-dependent restoration of spermatogenesis in contexts of experimental androgen withdrawal (O'Donnell et al. 1996, 1999), and possibly for the initiation of male germ development at puberty (Killian et al. 2003). As a potential regulator of testicular Srd5a1 expression, GATA4 might be an equally important participant in these processes. GATA-dependent regulation might also be important in the regulation of Srd5a1 expression in extra-gonadal tissues where GATA factors and SRD5A1 are co-expressed such as the skin and prostate (Perez-Stable et al. 2000, Kaufman et al. 2003, Azzouni et al. 2012).

Steroid hormones are derived from cholesterol. The steroidogenic capacity of a cell is therefore governed not only by regulating the enzymes that act upon cholesterol to convert it into steroids but also by regulating the availability of cholesterol itself. Steroidogenic cells such as Leydig cells use different mechanisms to obtain the cholesterol required for steroidogenesis. This includes uptake of cholesterol bound to circulating lipoproteins, mobilization of cholesterol esters stored in lipid droplets, and de novo cholesterol synthesis (reviewed in Miller \& Bose (2011)). Interestingly, in addition to steroidogenic genes, GATA4 appears to be an active participant in the control of Leydig cell cholesterol metabolism as several genes (Scarb1, Ldlr, Soat1, Scap, and Cyp51) controlling different aspects of cholesterol transport and synthesis were found to be downregulated in GATA4-depleted MA-10 cells (Table 3). Downregulated expression of these genes, along with the multiple steroidogenic targets, likely contribute to the significant decrease in MA-10 progesterone production observed in response to GATA4 knockdown (Fig. 7). Although we have yet to ascertain whether these novel cholesterol regulatory genes are direct GATA4 targets, the promoter region of at least one of these genes, Soat1, has been previously reported to be a target for the nuclear receptor NR5A1 (Ferraz-de-Souza et al. 2011), a factor known to cooperate with GATA4 on a variety of different steroidogenic promoters (Tremblay \& Viger 1999).

The reduction in Gata4 expression in MA-10 cells also led to a significant upregulation of several genes (Table 2). The most highly upregulated genes were Itgb8 and Vcan, encoding for proteins involved in cellcell interaction and the regulation of cell proliferation and migration. While the expression of one of the genes (Itgb8) has been recently shown to be highly enriched in fetal Leydig cells (McDowell et al. 2012), the physiological significance of these genes for Leydig cell function and their regulation by GATA4 remain unknown. More interestingly were upregulated genes encoding for transcription factors known for their more conspicuous participation in steroidogenesis. These included the proto-oncogene JUN, and the nuclear receptors NR2F2 (COUP-TFII) and NR4A2 (NURR1). JUN is a well-characterized regulator of Star expression in Leydig cells (Stocco et al. 2005); a regulation that appears to involve a synergistic interaction between JUN and GATA4 itself (Martin et al. 2012). Homozygous male mice carrying a conditional $\mathrm{Nr} 2 \mathrm{f2}$ deletion are infertile due to deficits in Leydig cell differentiation and reduced testosterone production (Qin et al. 2008). Whether NR2F2 directly targets steroidogenic genes in Leydig cells, however, remains to be shown (Martin \& Tremblay 2010). NR4A2 belongs to the NR4A family of nuclear receptors that have been shown to activate several promoters active in Leydig cells including Star, HSD3B2, Hsd3b1, and Cyp17a1 (Martin \& Tremblay 2010). Interestingly, the targets putatively regulated by JUN and NR4A proteins were identified as downregulated targets in our screening of GATA4-deficient MA-10 cells. It is therefore tempting to speculate that upregulation of JUN, NR2F2, and NR4A2 is a compensatory response of MA-10 cells to offset the decrease in steroidogenic gene expression or to increase Gata4 expression itself in MA-10 cells deficient in GATA4. The demonstration that JUN can directly activate Gata4 transcription would support at least the latter possibility (Murray et al. 2013).

In conclusion, our microarray study of GATA4depleted MA-10 cells identifies this factor as an essential contributor to Leydig cell steroidogenesis via the regulation of a network of genes intimately involved in cholesterol delivery and the steroidogenic program itself. Given this important role, GATA4 needs to be given close attention as a potential causative factor in human pathologies that are associated with reduced fertility and diminished steroid hormone synthesis.

\section{Supplementary data}

This is linked to the online version of the paper at http://dx.doi. org/10.1530/REP-14-0369.

\section{Declaration of interest}

The authors declare that there is no conflict of interest that could be perceived as prejudicing the impartiality of the research reported.

\section{Funding}

This work was supported by a grant (MOP-14796) from the Canadian Institutes of Health Research (CIHR) to R S Viger.

\section{Acknowledgements}

Drs Mario Ascoli (MA-10 cell line) and Jose Teixeira (-1.6 kb Amhr2 promoter-luciferase construct) are thanked for generously providing materials used in this study. Mathieu Gauthier is 
thanked for cloning and preparing the rat Srd5a1 promoterluciferase construct. Dr Clémence Belleannée is thanked for helping with the microarray analysis. The authors thank Dr Séverine Mazaud-Guittot for the critical reading of the manuscript. Gabriel Nadeau received a summer studentship from the NSERC CREATE training program in reproductive biology.

\section{References}

Ascoli M 1981 Characterization of several clonal lines of cultured Leydig tumor cells: gonadotropin receptors and steroidogenic responses. Endocrinology 108 88-95. (doi:10.1210/endo-108-1-88)

Azzouni F, Godoy A, Li Y \& Mohler J 2012 The $5 \alpha$-reductase isozyme family: a review of basic biology and their role in human diseases. Advances in Urology 2012 530121. (doi:10.1155/2012/530121)

Bennett J, Wu YG, Gossen J, Zhou P \& Stocco C 2012 Loss of GATA-6 and GATA-4 in granulosa cells blocks folliculogenesis, ovulation, and follicle stimulating hormone receptor expression leading to female infertility. Endocrinology 153 2474-2485. (doi:10.1210/en.2011-1969)

Bielinska M, Seehra A, Toppari J, Heikinheimo M \& Wilson DB 2007 GATA-4 is required for sex steroidogenic cell development in the fetal mouse. Developmental Dynamics 236 203-213. (doi:10.1002/dvdy.21004)

Bouchard MF, Taniguchi H \& Viger RS 2005 Protein kinase A-dependent synergism between GATA factors and the nuclear receptor, liver receptor homolog-1, regulates human aromatase (CYP19) PII promoter activity in breast cancer cells. Endocrinology 146 4905-4916. (doi:10.1210/en. 2005-0187)

Boulende Sab A, Bouchard MF, Beland M, Prud'homme B, Souchkova O, Viger RS \& Pilon N 2011 An Ebox element in the proximal Gata4 promoter is required for Gata4 expression in vivo. PLoS ONE 6 e29038. (doi:10.1371/journal.pone.0029038)

Chlon TM \& Crispino JD 2012 Combinatorial regulation of tissue specification by GATA and FOG factors. Development 139 3905-3916. (doi:10.1242/dev.080440)

Efimenko E, Padua MB, Manuylov NL, Fox SC, Morse DA \& Tevosian SG 2013 The transcription factor GATA4 is required for follicular development and normal ovarian function. Developmental Biology 381 144-158. (doi:10.1016/j.ydbio.2013.06.004)

Ferraz-de-Souza B, Hudson-Davies RE, Lin L, Parnaik R, Hubank M, Dattani MT \& Achermann JC 2011 Sterol O-acyltransferase 1 (SOAT1, ACAT) is a novel target of steroidogenic factor-1 (SF-1, NR5A1, Ad4BP) in the human adrenal. Journal of Clinical Endocrinology and Metabolism 96 E663-E668. (doi:10.1210/jc.2010-2021)

Hossain A \& Saunders GF 2003 Synergistic cooperation between the $\beta$-catenin signaling pathway and steroidogenic factor 1 in the activation of the Mullerian inhibiting substance type II receptor. Journal of Biological Chemistry 278 26511-26516. (doi:10.1074/jbc.M300804200)

Hu YC, Okumura LM \& Page DC 2013 Gata4 is required for formation of the genital ridge in mice. PLoS Genetics 9 e1003629. (doi:10.1371/ journal.pgen.1003629)

Imai T, Kawai $Y$, Tadokoro $Y$, Yamamoto $M$, Nishimune $Y$ \& Yomogida $K$ 2004 In vivo and in vitro constant expression of GATA-4 in mouse postnatal Sertoli cells. Molecular and Cellular Endocrinology 214 107-115. (doi:10.1016/j.mce.2003.10.065)

Jackson AL \& Linsley PS 2010 Recognizing and avoiding siRNA off-target effects for target identification and therapeutic application. Nature Reviews. Drug Discovery 9 57-67. (doi:10.1038/nrd3010)

Johansson AS \& Mannervik B 2001 Human glutathione transferase A3-3, a highly efficient catalyst of double-bond isomerization in the biosynthetic pathway of steroid hormones. Journal of Biological Chemistry 276 33061-33065. (doi:10.1074/jbc.M104539200)

Jordan M \& Wurm F 2004 Transfection of adherent and suspended cells by calcium phosphate. Methods 33 136-143. (doi:10.1016/j.ymeth.2003. 11.011)

Kaufman CK, Zhou P, Pasolli HA, Rendl M, Bolotin D, Lim KC, Dai X, Alegre ML \& Fuchs E 2003 GATA-3: an unexpected regulator of cell lineage determination in skin. Genes and Development 17 2108-2122. (doi:10.1101/gad.1115203)
Killian J, Pratis K, Clifton RJ, Stanton PG, Robertson DM \& O'Donnell L $20035 \alpha$-reductase isoenzymes 1 and 2 in the rat testis during postnatal development. Biology of Reproduction 68 1711-1718. (doi:10.1095/ biolreprod.102.009142)

King SR \& LaVoie HA 2012 Gonadal transactivation of STARD1, CYP11A1 and HSD3B. Frontiers in Bioscience 17 824-846. (doi:10.2741/3959)

Klattig J, Sierig R, Kruspe D, Besenbeck B \& Englert C 2007 Wilms' tumor protein Wt1 is an activator of the anti-Müllerian hormone receptor gene Amhr2. Molecular and Cellular Biology 27 4355-4364. (doi:10.1128/ MCB.01780-06)

Kobayashi M \& Yamamoto M 2007 Regulation of GATA1 gene expression. Journal of Biochemistry 142 1-10. (doi:10.1093/jb/mvm122)

Kwintkiewicz J, Cai Z \& Stocco C 2007 Follicle-stimulating hormoneinduced activation of Gata4 contributes in the up-regulation of Cyp19 expression in rat granulosa cells. Molecular Endocrinology 21 933-947. (doi:10.1210/me.2006-0446)

Kyrönlahti A, Euler R, Bielinska M, Schoeller EL, Moley KH, Toppari J, Heikinheimo M \& Wilson DB 2011a GATA4 regulates Sertoli cell function and fertility in adult male mice. Molecular and Cellular Endocrinology 333 85-95. (doi:10.1016/j.mce.2010.12.019)

Kyrönlahti A, Vetter $M$, Euler R, Bielinska $M$, Jay PY, Anttonen $M$, Heikinheimo M \& Wilson DB 2011b GATA4 deficiency impairs ovarian function in adult mice. Biology of Reproduction 84 1033-1044. (doi:10. 1095/biolreprod.110.086850)

LaVoie HA 2003 The role of GATA in mammalian reproduction. Experimental Biology and Medicine 228 1282-1290.

Lei N \& Heckert LL 2004 Gata4 regulates testis expression of Dmrt1. Molecular and Cellular Biology 24 377-388. (doi:10.1128/MCB.24.1. 377-388.2004)

Manuylov NL, Fujiwara Y, Adameyko II, Poulat F \& Tevosian SG 2007 The regulation of Sox 9 gene expression by the GATA4/FOG2 transcriptional complex in dominant XX sex reversal mouse models. Developmental Biology 307 356-367. (doi:10.1016/j.ydbio.2007.04.040)

Manuylov NL, Smagulova FO, Leach L \& Tevosian SG 2008 Ovarian development in mice requires the GATA4-FOG2 transcription complex. Development 135 3731-3743. (doi:10.1242/dev.024653)

Manuylov NL, Zhou B, Ma Q, Fox SC, Pu WT \& Tevosian SG 2011 Conditional ablation of Gata4 and Fog2 genes in mice reveals their distinct roles in mammalian sexual differentiation. Developmental Biology 353 229-241. (doi:10.1016/j.ydbio.2011.02.032)

Martin LJ \& Tremblay JJ 2010 Nuclear receptors in Leydig cell gene expression and function. Biology of Reproduction 83 3-14. (doi:10. 1095/biolreprod.110.083824)

Martin LJ, Taniguchi H, Robert NM, Simard J, Tremblay JJ \& Viger RS 2005 GATA factors and the nuclear receptors, steroidogenic factor $1 /$ liver receptor homolog 1 , are key mutual partners in the regulation of the human $3 \beta$-hydroxysteroid dehydrogenase type 2 promoter. Molecular Endocrinology 19 2358-2370. (doi:10.1210/me.2004-0257)

Martin LJ, Bergeron F, Viger RS \& Tremblay JJ 2012 Functional cooperation between GATA factors and cJUN on the star promoter in MA-10 Leydig cells. Journal of Andrology 33 81-87. (doi:10.2164/ jandrol.110.012039)

Matsumura T, Imamichi Y, Mizutani T, Ju Y, Yazawa T, Kawabe S, Kanno M, Ayabe T, Katsumata N, Fukami M, Inatani M et al. 2013 Human glutathione $S$-transferase A (GSTA) family genes are regulated by steroidogenic factor 1 (SF-1) and are involved in steroidogenesis. FASEB Journal 27 3198-3208. (doi:10.1096/fj.12-222745)

Mazaud Guittot S, Tetu A, Legault E, Pilon N, Silversides DW \& Viger RS 2007 The proximal Gata4 promoter directs reporter gene expression to sertoli cells during mouse gonadal development. Biology of Reproduction 76 85-95. (doi:10.1095/biolreprod.106.055137)

McDowell EN, Kisielewski AE, Pike JW, Franco HL, Yao HH \& Johnson KJ 2012 A transcriptome-wide screen for mRNAs enriched in fetal Leydig cells: CRHR1 agonism stimulates rat and mouse fetal testis steroidogenesis. PLOS ONE 7 e47359. (doi:10.1371/journal.pone.0047359)

Miller WL \& Bose HS 2011 Early steps in steroidogenesis: intracellular cholesterol trafficking. Journal of Lipid Research 52 2111-2135. (doi:10. 1194/j|r.R016675)

Miyamoto Y, Taniguchi H, Hamel F, Silversides DW \& Viger RS 2008 A GATA4/WT1 cooperation regulates transcription of genes required for mammalian sex determination and differentiation. BMC Molecular Biology 9 44. (doi:10.1186/1471-2199-9-44) 
Molkentin JD 2000 The zinc finger-containing transcription factors GATA-4, -5 , and -6 . Ubiquitously expressed regulators of tissue-specific gene expression. Journal of Biological Chemistry 275 38949-38952. (doi:10. 1074/jbc.R000029200)

Murray TV, Smyrnias I, Shah AM \& Brewer AC 2013 NADPH oxidase 4 regulates cardiomyocyte differentiation via redox activation of c-Jun protein and the cis-regulation of GATA-4 gene transcription. Journal of Biological Chemistry 288 15745-15759. (doi:10.1074/jbc.M112. 439844)

O'Donnell L, Stanton PG, Wreford NG, Robertson DM \& McLachlan RI 1996 Inhibition of $5 \alpha$-reductase activity impairs the testosteronedependent restoration of spermiogenesis in adult rats. Endocrinology 137 2703-2710.

O'Donnell L, Pratis K, Stanton PG, Robertson DM \& McLachlan RI 1999 Testosterone-dependent restoration of spermatogenesis in adult rats is impaired by a $5 \alpha$-reductase inhibitor. Journal of Andrology 20 109-117. (doi:10.1002/j.1939-4640.1999.tb02503.x)

Parker KL, Rice DA, Lala DS, Ikeda Y, Luo X, Wong M, Bakke M, Zhao L, Frigeri C, Hanley NA et al. 2002 Steroidogenic factor 1: an essential mediator of endocrine development. Recent Progress in Hormone Research 57 19-36. (doi:10.1210/rp.57.1.19)

Peng L, Huang Y, Jin F, Jiang SW \& Payne AH 2004 TEF-5 and a GATA-like protein determine placental-specific expression of the type I human $3 \beta$-hydroxysteroid dehydrogenase gene, HSD3B1. Molecular Endocrinology 18 2049-2060. (doi:10.1210/me.2004-0028)

Perez-Stable CM, Pozas A \& Roos BA 2000 A role for GATA transcription factors in the androgen regulation of the prostate-specific antigen gene enhancer. Molecular and Cellular Endocrinology 167 43-53. (doi:10. 1016/S0303-7207(00)00300-2)

Qin J, Tsai MJ \& Tsai SY 2008 Essential roles of COUP-TFII in Leydig cell differentiation and male fertility. PLOS ONE 3 e3285. (doi:10.1371/ journal.pone.0003285)

Racine C, Rey R, Forest MG, Louis F, Ferre A, Huhtaniemi I, Josso N \& di Clemente N 1998 Receptors for anti-Mullerian hormone on Leydig cells are responsible for its effects on steroidogenesis and cell differentiation. PNAS 95 594-599. (doi:10.1073/pnas.95.2.594)

Raffalli-Mathieu F, Orre C, Stridsberg M, Hansson Edalat M \& Mannervik B 2008 Targeting human glutathione transferase A3-3 attenuates progesterone production in human steroidogenic cells. Biochemical Journal 414 103-109. (doi:10.1042/BJ20080397)

Ringner M 2008 What is principal component analysis? Nature Biotechnology 26 303-304. (doi:10.1038/nbt0308-303)

Robert NM, Miyamoto Y, Taniguchi H \& Viger RS 2006 LRH-1/NR5A2 cooperates with GATA factors to regulate inhibin $\alpha$-subunit promoter activity. Molecular and Cellular Endocrinology 257-258 65-74. (doi:10. 1016/j.mce.2006.06.011)

Seenundun S \& Robaire B 2005 Cloning and characterization of the $5 \alpha-$ reductase type 2 promoter in the rat epididymis. Biology of Reproduction 72 851-861. (doi:10.1095/biolreprod.104.033746)

Sher N, Yivgi-Ohana N \& Orly J 2007 Transcriptional regulation of the cholesterol side chain cleavage cytochrome P450 gene (CYP11A1) revisited: binding of GATA, cyclic adenosine $3^{\prime}, 5^{\prime}$-monophosphate response element-binding protein and activating protein (AP)-1 proteins to a distal novel cluster of cis-regulatory elements potentiates AP-2 and steroidogenic factor-1-dependent gene expression in the rodent placenta and ovary. Molecular Endocrinology 21 948-962. (doi:10.1210/me. 2006-0226)

Shi Y, Schonemann MD \& Mellon SH 2009 Regulation of P450c17 expression in the early embryo depends on GATA factors. Endocrinology 150 946-956. (doi:10.1210/en.2008-0573)

Shih MC, Chiu YN, Hu MC, Guo IC \& Chung BC 2011 Regulation of steroid production: analysis of Cyp11a1 promoter. Molecular and Cellular Endocrinology 336 80-84. (doi:10.1016/j.mce.2010.12.017)

Silverman E, Eimerl S \& Orly J 1999 CCAAT enhancer-binding protein beta and GATA-4 binding regions within the promoter of the steroidogenic acute regulatory protein (StAR) gene are required for transcription in rat ovarian cells. Journal of Biological Chemistry 274 17987-17996. (doi:10.1074/jbc.274.25.17987)
Simard J, Ricketts ML, Gingras S, Soucy P, Feltus FA \& Melner MH 2005 Molecular biology of the $3 \beta$-hydroxysteroid dehydrogenase $/ \delta 5-\delta 4$ isomerase gene family. Endocrine Reviews 26 525-582. (doi:10.1210/ er.2002-0050)

Stocco DM, Wang X, Jo Y \& Manna PR 2005 Multiple signaling pathways regulating steroidogenesis and steroidogenic acute regulatory protein expression: more complicated than we thought. Molecular Endocrinology 19 2647-2659. (doi:10.1210/me.2004-0532)

Teixeira J, Kehas DJ, Antun R \& Donahoe PK 1999 Transcriptional regulation of the rat Mullerian inhibiting substance type II receptor in rodent Leydig cells. PNAS 96 13831-13838. (doi:10.1073/pnas.96.24.13831)

Teixeira J, Maheswaran S \& Donahoe PK 2001 Mullerian inhibiting substance: an instructive developmental hormone with diagnostic and possible therapeutic applications. Endocrine Reviews 22 657-674. (doi:10.1210/edrv.22.5.0445)

Tevosian SG 2014 Transgenic mouse models in the study of reproduction: insights into GATA protein function. Reproduction 148 R1-R14. (doi:10. 1530/REP-14-0086)

Tevosian SG, Albrecht KH, Crispino JD, Fujiwara Y, Eicher EM \& Orkin SH 2002 Gonadal differentiation, sex determination and normal Sry expression in mice require direct interaction between transcription partners GATA4 and FOG2. Development 129 4627-4634.

Tremblay JJ \& Viger RS 1999 Transcription factor GATA-4 enhances Müllerian inhibiting substance gene transcription through a direct interaction with the nuclear receptor SF-1. Molecular Endocrinology 13 1388-1401. (doi:10.1210/mend.13.8.0330)

Tremblay JJ \& Viger RS 2001 GATA factors differentially activate multiple gonadal promoters through conserved GATA regulatory elements. Endocrinology 142 977-986. (doi:10.1210/endo.142.3.7995)

Tremblay JJ \& Viger RS 2003a Novel roles for GATA transcription factors in the regulation of steroidogenesis. Journal of Steroid Biochemistry and Molecular Biology 85 291-298. (doi:10.1016/S0960-0760(03)00211-5)

Tremblay JJ \& Viger RS 2003b Transcription factor GATA-4 is activated by phosphorylation of serine 261 via the cAMP/PKA pathway in gonadal cells. Journal of Biological Chemistry 278 22128-22135. (doi:10.1074/ jbc.M213149200)

Viger RS \& Robaire B 1995 Steady state steroid $5 \boldsymbol{\alpha}$-reductase messenger ribonucleic acid levels and immunocytochemical localization of the type 1 protein in the rat testis during postnatal development. Endocrinology 136 5409-5415. (doi:10.1210/endo.136.12.7588289)

Viger RS, Mertineit C, Trasler JM \& Nemer M 1998 Transcription factor GATA-4 is expressed in a sexually dimorphic pattern during mouse gonadal development and is a potent activator of the Müllerian inhibiting substance promoter. Development 125 2665-2675.

Viger RS, Taniguchi H, Robert NM \& Tremblay JJ 2004 Role of the GATA family of transcription factors in andrology. Journal of Andrology 25 441-452. (doi:10.1002/j.1939-4640.2004.tb02813.x)

Wooton-Kee CR \& Clark BJ 2000 Steroidogenic factor-1 influences protein-deoxyribonucleic acid interactions within the cyclic adenosine 3,5-monophosphate-responsive regions of the murine steroidogenic acute regulatory protein gene. Endocrinology 141 1345-1355. (doi:10. 1210/endo.141.4.7412)

Viger RS, Mazaud Guittot S, Anttonen M, Wilson DB \& Heikinheimo M 2008 Role of the GATA family of transcription factors in endocrine development, function, and disease. Molecular Endocrinology 22 781-798. (doi:10.1210/me.2007-0513)

Zaytouni T, Efimenko EE \& Tevosian SG 2011 GATA transcription factors in the developing reproductive system. Advances in Genetics 76 93-134.

Zhang Z, Wu AZ, Feng ZM, Mruk D, Cheng CY \& Chen CL 2002 Gonadotropins, via CAMP, negatively regulate GATA-1 gene expression in testicular cells. Endocrinology 143 829-836. (doi:10.1210/endo.143. 3.8688)

Received 23 July 2014

First decision 7 August 2014

Revised manuscript received 21 November 2014

Accepted 11 December 2014 